\title{
Short and/or long-term investment choice: Artificial intelligence analysis of the role of both or- ganizational and behavioral determinants
}

\author{
Fadhila Hamza ${ }^{a^{*}}$
}

${ }^{a}$ Department Accounting, College of Business and Administration, Princess Nourah bint Abdulrahman University, Saudi Arabia C H R O N I L E A B S T RACT

\begin{tabular}{l} 
Article history: \\
Received: June 18, 2021 \\
Received in revised format: June \\
29,2021 \\
Accepted: September 22, 2021 \\
Available online: September 22, \\
2021 \\
\hline Keywords: \\
Commitment bias \\
Investment horizon choice \\
Bayesian network \\
Myopia \\
The locus of control \\
Governance mechanisms
\end{tabular}

\begin{abstract}
This paper shows empirically the impact of organizational and behavioral determinants on the CEO's investment horizon choice, using artificial intelligence explanatory methods. We apply our approach to 100 Saudi firms. We test the effect of three organizational determinants: ownership concentration, board independence, and CEO remuneration system; and three behavioral determinants: myopia, the locus of control and commitment, on the CEO's investment horizon choice. The study's key finding is that executives' commitment bias is the most important variable in terms of modal value that affects firms' long-term investment choice. We also find a positive and significant relationship between myopia and long-term investment choice, whereas the lowliest determinant of the horizon choice is the locus of control. More generally, these results show that CEOs who are likely to be the most myopic may display long-term behavior with the existence of high cognitive involvement.
\end{abstract}

(C) 2022 by the authors; licensee Growing Science, Canada.

\section{Introduction}

Previous studies supposed that the main responsibility of executives is the maximization of long-term shareholders' wealth. This prominent accountability is commonly believed as an attitude but imperfectly fulfilled as a behavior. Thus, several CEOs; reacting to pressure from stakeholders or performing to reinforce their own situation; orientate their commitment and employ their abilities to accomplish short-term profitability, essentially avoiding longer-term concerns. Investment decision making has been extensively discussed in the financial literature for quite some time while the importance of understanding the determinants of investment behavior is undisputed. Thus, there is a lack of consensus on the conceptual framework of decision making. Investment horizon is the result of an interconnected network of determinants. Warren (2014) identifies twelve determinants under four broad groups. Some related to the conditions of the investor (example: the means of funding, the structure of liabilities, and the tolerance for illiquidity, etc.). Meanwhile, some investors usually have a short-term horizon while others are tolerant of long-term choices. Additional set of determinants are in relationship to the architecture of the environment in which investment choices are being designed. Most of these determinants are organizational features such as governance mechanisms; others are related to the structure of financial markets (Gutiérrez and Philippon 2016). Horizon is also highly related to decision-maker attitude and practice, and the nature of the information that is considered when deciding investment choices. Therefore, the author cites some behavioral and psychological effects and supposes that even the personal attitudes and cognitions of decision makers have a high impact on how choices are decided. Thus, several studies have been conducted on the psychology of investment (Warneryd, 2001). Numerous variables like cognitions, intentions, preferences, and behavioral and psychological biases have been discussed (Hilton, 2001; De Bondt, 1998; Daniel et al., 2002; Kahneman \& Riepe, 1998).

* Corresponding author

E-mail address: fahamza@pnu.edu.sa (F. Hamza)

(C) 2022 by the authors; licensee Growing Science, Canada. doi: $10.5267 /$ j.ijdns.2021.9.012 
Additionally, if ones go through the psycho-sociological literature, they find that subjective norms and decider's attitudes, affections, and beliefs at the time of decision-making have a crucial impact on choices intended (the theory of reasoned actions (Ajzen \& Sheikh, 2013; Ke Zhang; 2018) and the theory of persuasion (Bonetto et al., 2018)). While, the actual decision reflects that ethical and authentic choices are made only by involved persons (the theory of commitment (Joule et al., 2007, 2008). To date, however, there has been very little work on the impact of a CEO's cognitive commitment on the investment decision. This study intends to examine the impact of both organizational and cognitive factors on executives' decision-making. The model will help to investigate the relationship between governance mechanisms (ownership concentration, board independence, and remuneration system), cognitive bias (myopia, a locus of control, and commitment), and horizon investment decision.

\section{Literature review and hypotheses}

\subsection{Organizational Determinants of Short-Term Investment choice}

As the shareholder investment horizon is based on two key conducts, "pressure" and "walk" (Duruigbo, 2011), some shareholders; researchers for rapid return on investment; stressed their executives to concentrate on short-term return, even to the detriment of long-term wealth. Moreover, this type of shareholders would rather sell their stock if they were dissatisfied with direction rather than keep them and influence management and corporate strategy. Eventually, this acts against good firm performance (Gutiérrez \& Philippon, 2017). While long-term owners have objectives that go beyond instantaneously shortterm return's maximization. They are well placed to support firm strategies that are in convergence with common societal preferences of organizations (Hill, 2007). Undeniably, insofar as firms get orientated on the short term, the default to provide appropriate consideration to environmental, social, or ethical topics may cause reputational destruction, stock price volatility and cost of capital augmentation (Williams \& Conley, 2005). Generally, block holders tend to focus on their firms' social and environmental responsibility since they know that paying no attention to these issues may eventually engender a weighty menace to their financial reputation. Consequently, block holders suggest that long-run strategies should converge with the benefits of long-term owners and limit the influence of short horizon investors. The common interest of block holders is that owning shares for the long term, instead of considering themselves as passengers trying to behave the best during their shortterm staying, without tolerable concern to what occurs when they leave (Hill, 2010). Accordingly, block holders, who are conscious of long-term corporate performance, become fixated to persuade executives that the long-run perspective is the adequate target. Therefore, topics about discretion may be managed by several approaches of control and persuasion proposed by the agency theory (Shleifer \& Vishny, 1986; Agrawal \& Mandelker, 1990; Holderness, 2002).

\section{Hypothesis: $\mathbf{H}_{1}$ : The existence of block holders is negatively related to a long-term investment horizon.}

It is known that under the shareholder-focused agency model, the role of the board of directors is to monitor management to raise the company's long-term performance (Fama, 1980; Fama \& Jensen, 1983; Rappaport, 2005; Dallas, 2012; Sappideen, 2011). Directors were called to improve choices that privileged, especially the long run, the company and shareholders' wealth. Thus, when the board is confronted with alternative strategic decisions, they should prefer decisions that would favor the shareholders' interests in the long run. Directors that prove engagement would exercise high influence on corporate governance and decision-making. Gonzalez and André (2014) find that companies with more effective boards are related to inferior short-term risks and this result is significant to various natures of short-term risk and specifications. Consequently, authors believe that an effective board has a great role in monitoring management, making them responsible, and implant a long-term vision of firm performance. Gonzalez and André (2014) recognized the important role of board independence and the presence of outside directors as an indicator of board effectiveness in monitoring management and decreasing the agency costs associated with the separation of control and management in contemporary corporations. An effective board must reduce short horizon or short-term risk-taking by executives. Ashbaugh-Skaife et al. (2009) show that if governance system weakens the adverse selection and moral hazard issues, effective board diminishes corporate risk consequential to inferior idiosyncratic risk, negligible $\beta$ s and lower cost of equity. Accordingly, the influence of board independence on the executives' decision horizon is also consistent with the prominent argument of outside directors' reputation on the labor market (Rubin and Segal, 2011). Interestingly, the role of directors is not only based on the predominance of shareholders' interests, however, the preservation of corporate long-term strategies will comfort both the shareholders and the other corporation's partners whose interests are guaranteed by the long-term firm's performance. Good directors' reputation will be connected to monitoring management in order to focus on the long term owners' wealth but also the maximization of the rest stakeholders' interests because a firm that performs well in the long horizon will further safeguard the interests of all partners, such shareholders, employees, vendors, customers, and societies.

\section{Hypothesis $\mathbf{H}_{2}$ : Board independence is negatively associated with short-term investment choice.}

Executives have their own goals and interests as individuals. Agency theory proposes that compensation forms are required to decrease conflict of interests between managers and shareholders (Murphy, 1999; Jensen \& Murphy, 1990; Duruigbo 2011). Particularly, it shows how incentive schemes may condition the level to which firm strategies' horizons will be transformed into higher manager revenue. 
The nature of executive compensation schemes affects executive choices' horizons. The implementation of sophisticated, flexible or equity-based manager incentives is a means to resolve agency problems by contracting managers' compensation that increase corporate performance. Executives may show moral hazard by persevering investments with earlier benefit, even risky investments, due to inadequate long-term incentives. Thus, Laverty (1996) validates that opportunistic manager may avoid long-term investment choices, vital for the prospect benefit of the corporation, in order to focus on further alternatives whose short-term profit enhancements permit them to increase their individual incentives.

Remuneration through stocks and stock options may drive executives to manipulate financial statements to enhance stock prices in the short term for their interest to sell or exercise the options (Duruigbo, 2011). Remarkably, short-term shareholders are probably to encourage providing stock options to managers, considering that it may persuade managers to implement a favorable behavior in the short term even if uncomfortable for the long run corporation.

Inversely, Jesse (2011) postulates that stock-based incentives serve the interests of both executives and shareholders by persuading managers to maximize shareholders' value and corporate long-term performance (Jesse, 2011). Thus, we aim to test the following hypothesis:

Hypothesis $\mathbf{H}_{3}$ : The performance-based executive's compensation is negatively associated with short-term investment choice.

\subsection{Behavioral Determinants}

While it could be real that executives occasionally react to shareholders' short-term pressure, executives may also be individualistically myopic (Duruigbo, 2011). Interestingly, "managers might rationally behave myopically as a result of a sort of prisoner's dilemma, in which they are trapped in myopic behavior even if they know that the market would be efficient in equilibrium" (Duruigbo, 2011). Therefore, executives' myopic attitudes can be induced whether by internal or external impacts. At the inter-individual level, beliefs and cognition are essential for implanting longer-term attitude change. As defined by Jeffrey (2005), attitudes help persons to determine how he perceives situations, as well as define how he acts face to face. Interestingly, attitudes include emotions, judgments, and actions; simply, it is a long-term estimation and indicator of individual behaviors. Consequently, CEOs' attitudes toward myopic investment horizon include his beliefs about the task; how he feels about this task; as well as how he acts as an influential attitude to longer-term investment. On the other hand, regarding UET theory (Hambrick, et al., 2005; Hambrick, 2007) and the theory of governance (Charreaux, 2008; Wirtz, 2011) external influences may be resumed within the governance system. Mechanisms' intervention aims to guide the conduct in which managers believe, behave and perform, either in the individual scale or in the under group level.

Thus, we hypothesize as follow:

Hypothesis $\mathbf{H}_{4}$ : The CEOs myopia will have a positive influence on the short-term investment choice.

Researchers in the managerial discretion determinants (Miller et al., 1982; Finkelstein \& Hambrick, 1996) identify various CEOs cognitive features such, tolerance toward ambiguity, accomplishment desire, and the concept of "locus of control".

The long-run performance of a firm is related to the decision making abilities of the CEOs and such studies have been provided to define the qualities and features that are shared between successful decision makers (Finkelstein \& Hambrick, 1996; Papenhausen, 2006; Wally \& Baum, 1994). Locus of control is, "a generalized expectancy reflecting the degree to which individuals perceive consequences as contingent on their own behavior and abilities (internal control) rather than on some external force such as luck, chance, fate, or powerful others (external control)" (Janssen \& Carton, 1999, p. 1).

The concept "locus of control" conveys the idea of control that individual beliefs have about the events and actions. Miller et al. (1982) show that there is a direct link between this notion and the nature of strategy, they found that CEOs locus of control was largely related to organizational policy and choices in small firms.

Commonly, persons with higher locus of control are persons who have large confidence in their abilities to select the right decisions and to execute these decisions through determined effort. This self-confidence and the perceived facility of tasks "locus of control" influence a person's behavioral intention (Hambrick, 2007).

CEOs locus of control has received great attention as a personal characteristic (Hambrick and Abrahamson, 1995; Mitchell et al., 2009). Managers who have a strong belief that decisions are under their control, have an internal locus of control. Consequently, based on his internal locus of control perception, the manager reveals more expertise while making decisions and so has more discretion.

Jackson, et al., (2000) demonstrate that locus of control can manage stress by rising optimism. Internal locus of control conducts individuals to believe that he is in control, and he is consistent and responsible for his behaviors. Therefore, a decider with an internal locus of control considers that he can do well and so, is optimistic. This optimism and higher perception of control promote the chances and desires of accomplishment (Hambrick et al.; 2005) which reduces stress and raises the probability of undervaluing uncertainties and risks (Durand, 2003). Additionally, high level of internal "locus of control" indicates 
that overconfident managers consider that their behaviors are less determined by features external their control than by features under their control (Hiller \& Hambrick; 2005)

Consequently, the locus of control is one of the main predictors of individual behaviors (Bamberg \& Möser, 2007; Hiller \& Hambrick, 2005) and a personal determinant of managerial discretion concerns. The role of the locus of control in CEOs' behaviors toward decisions horizon may be evoked as a determinant of the decision-making process. This supposes that the manager has control over their behavioral consequences which is more effective in confronting executives' job demands. So, we hypothesize as follow:

Hypothesis $\mathbf{H}_{5}$ : The CEOs locus of control will have a negative influence on the short-term investment choice.

Most theories of behaviour' change (the theory of reasoned action (Fishbein and Ajzen, 1975), the theory of planned behavior (Ajzen, 2012; Ajzen and Sheikh, 2013; Ke Zhang, 2018), and expectancy-value theories (Feather and Newton, 1982; Fishbein, 1963; Plante et al., 2012), share the evidence that the unique best predictor of a person's behavior is, basically, his intention to adhere in that behavior. Fundamentally, all behaviors' change theories comprise some form of the concept of behavioral intention as a proximal generator of action.

Interestingly, decisions to behave authentically are the result of a valuation of the possibility of specific consequences related to the behavior along with the subjective significance allocated to those results. When the valuation provides a positive consequence, the decision pushes usually to behavior. Therefore, that decision is the behavioral intention, which is the single predictor of behavior.

Accordingly, people will feel personally committed by the act they were persuaded into doing. We can so comprehend why Charles Kiesler, the founder of the theory of commitment, chose to describe commitment as the link that connects individuals to their actions. It is just to understand that the link will be more solid when individuals behave in a context of a commitment than in one of discipline, also, subjects commit to their behaviors according to their attitudes. As a result, Joule et al., (2007) present the notion of internal and external commitment. Stimulating by our hypothesis we mention here the internal commitment which is defined by Argyris (1999) that "As the name implies, internal commitment comes largely from within. Individuals are committed to a particular project, person, or program based on their own reasons or motivations".

For a long time, researchers (Hawley and Williams, 2000b) examine the mode employed in order to avoid short-termism through various structural changes. As Duruigbo (2011) discussed, discouraging short-term decision making and encouraging long-term behaviors is for firms' interests to stimulate the creation of long-term shareholders' wealth. As their main role, corporations would be persuaded to seek out long-term committed shareholders and admit their influence in governance.

Although, the subsequent logical phase in corporate governance is to back the persuasion with action (Duruigbo, 2011). One approach of backing the persuasion into action may be introduced by shareholders who may implement a strategy of commitment to drive managers' decisions for an ascertainable and extended horizon of time.

According to the theory of commitment (Joule et al., 2007), only freely acceptance and internalization of the long-horizon attitude and behavior could be a more active tactic of guaranteeing the alignment of long-horizon executive decisions. Moreover, the internalization of attitudes and actions ensures a high degree of compliance with those norms. Equally, when individuals have not internalized a related norm, not even the organizational or the market pressures may succeed in monitoring their behavior (Leslie, 2010). Consistently, we intend to test the following hypothesis:

Hypothesis $\mathbf{H}_{6}$ : A high level of commitment is negatively associated with the short-term investment choice.

\section{Research design:}

\subsection{Sample and data collection}

The present study is based on an empirical quantitative research methodology that aims to test the different correlations between the dependent and independent variables using the Bayesian network method that is inserted on the artificial intelligence explanatory methods. We test the hypotheses empirically using data from 100 Saudi firms. They only included non-financial companies. All financial firms and firms with unsatisfactory data regarding managers behavioral features were excluded.

The data were hand-collected from several sources: financial data were extracted from firms' financial reports and non-financial data related to CEOs' behavioral biases were collected through a questionnaire.

\subsection{Models specification}

The idea of this paper is showing the importance of some organizational and behavioral determinants on the CEO's investment behavior, especially, investment horizon choice. 
Horizon $=f$ (organizational determinants + behavioral determinants $)$

Further, we hypothesize that the presence of a solid monitoring and incentive system cannot effectively persuade the manager to decide long-term investment. It may change the CEO's attitude toward investment horizon (model 2) but not achieving a real behavior change. The existence of cognitive commitment links between the executive' attitude and behavior in investment horizon choice, ameliorate the role of persuasive mechanisms and lead, consequently, to a favorable behavior (model 1).

Thus, in the first model, we aim to study the impact of corporate governance mechanisms and behavioral bias on the investment horizon choice (Horizon). We introduce simultaneously the following independent variables: ownership concentration (OwC), board independence (Bind), incentive remuneration system (IRS), myopia (Myop), the locus of control (LC), and commitment bias (CB).

Horizon $=\beta_{0}+\beta_{1}$ BInd $_{i}+\beta_{2} O w C_{i}+\beta_{3} I R S_{i}+\beta_{4}$ Myopia $+\beta_{5} L C_{i}+\beta_{6} C B I+\mu_{i}$

In the second model, we aim to study the impact of corporate governance mechanisms and other behavioral bias on the CEO's myopic attitude. So, we introduce simultaneously the following independent variables: ownership concentration (OwC), board independence (Bind), incentive remuneration system (IRS), the locus of control (LC), and commitment bias (CB).

Myopia $=\beta_{0}+\beta_{1}$ BInd $_{i}+\beta_{2} O w C_{i}+\beta_{3} I R S_{i}+\beta_{4} L C_{i}+\beta_{5} C B I+\mu_{i}$

Table 1

Details of the dependent and independent variables of the two developed models

\begin{tabular}{|c|c|c|c|}
\hline Variables' names & Expected sign & Definition and measurement & Authors \\
\hline \multicolumn{4}{|c|}{ Dependent variable } \\
\hline Horizon & & $\begin{array}{l}\text { Is The investment horizon. Is measured using the Capital } \\
\text { Expenditure Rate (CER= operating assets / Total assets) }\end{array}$ & $\begin{array}{l}\text { Draief (2010), Azouzi and Jarboui } \\
\text { (2012) }\end{array}$ \\
\hline \multicolumn{4}{|c|}{ Independent variables } \\
\hline OwC & & $\begin{array}{l}\text { Is the ownership concentration. Is measured by the } \% \text { of } \\
\text { capital held by the block holder. It is dummy, set to } 1 \text { when } \\
\text { the }>50 \% \text { and } 0 \text { otherwise. }\end{array}$ & Shabou (2000) \\
\hline BInd & & $\begin{array}{l}\text { Is the board independence. Is measured by the } \% \text { of direc- } \\
\text { tors who are simultaneously independents and non-execu- } \\
\text { tives from the total board members. It is dummy, set to } 1 \\
\text { when the }>50 \% \text { and } 0 \text { otherwise. }\end{array}$ & $\begin{array}{l}\text { Azouzi and Jarboui, 2012, Hamza } \\
\text { et al., } 2014\end{array}$ \\
\hline RS & & $\begin{array}{l}\text { It is the CEO incentives. It is dummy, it takes } 1 \text { when the } \\
\text { manager's remuneration system is based on firm's perfor- } \\
\text { mance; and, } 0 \text { when it is fixed. }\end{array}$ & Hamza et al., 2014 \\
\hline Myopia & & $\begin{array}{l}\text { Is the CEO's myopia. takes } 1 \text { if the manager has a high } \\
\text { level of myopia bias, and } 0 \text { otherwise. }\end{array}$ & Bouwens and van Lent (2007) \\
\hline LoC & & $\begin{array}{l}\text { Is the Locus of control. Is measured using internal/external } \\
\text { Levenson's scale. }\end{array}$ & $\begin{array}{l}\text { Levenson's scale adjusted by } \\
\text { Paquet et al., (2012) }\end{array}$ \\
\hline CB & & $\begin{array}{l}\text { Is the CEO's commitment bias. Is measured using the Or- } \\
\text { ganizational Commitment Scale. }\end{array}$ & $\begin{array}{l}\text { Meyer et al., 2002; Hamza et al., } \\
2014\end{array}$ \\
\hline
\end{tabular}

\section{Results}

The relationship between variables in the parent node and child node is measured using three indicators: the Kullback-Leibler, the relative weight, and the Pearson correlation. Thus, Table 2 shows the relationships analysis between variables across the Bayesian network.

Table 2

The relationships analysis

\begin{tabular}{lllll}
\hline & & \multicolumn{2}{c}{ Model 1 } & \\
\hline PARENTS & CHILDS & KULLBACK-LEIBLER & RELATIVE & PEARSON \\
\hline LC & Horizon & 0.1068 & 0.8251 & -0.2166 \\
CB & Horizon & 0.0928 & 0.7168 & -0.0012 \\
OwC & Horizon & 0.0879 & 0.6794 & -0.0347 \\
BIND & Horizon & 0.0855 & 0.6603 & -0.0328 \\
MYOP & Horizon & 0.0786 & 0.6069 & 0.0554 \\
IRS & Horizon & 0.0668 & 0.5157 & -0.0940 \\
\hline PARENTS & & & Model 2 & RELATIVE \\
\hline CB & CHILDS & KULLBACK-LEIBLER & 1.0000 & PEARSON \\
IRS & MYOP & 0.1294 & 0.4243 & 0.3023 \\
BIND & MYOP & 0.0549 & 0.3905 & 0.0787 \\
LC & MYOP & 0.0505 & 0.3530 & -0.0059 \\
OwC & MYOP & 0.0457 & 0.3194 & -0.0535 \\
\hline
\end{tabular}


About the impact of governance mechanisms on the investment horizon decision (model 1); analysis shown in table 2 displays the presence of strong, negative and significant of ownership concentration $(\beta=-0.0347 * *)$, board independence $(\beta=-$ $0.0328 * *)$ and remuneration system $(\beta=-0.0940 *)$.

The displayed results demonstrate that shareholders and directors push managers to behave myopically. Similarly, Jackson and Petraki (2011) express that stakeholder may perform myopic behaviors or display a risk-aversion attitude to avoid insecurity about the long-run. As the long-term horizon for decision making influences the future firm's performance, the probability of uncertain circumstances increases.

Thus, the interdependence between instability and time horizons leads actors (especially block holders and outside directors) to privilege instantaneous payoff over long-term results because the future situations are beyond their control. Interestingly, Baz et al (1999, p.279) argue "the perception of long-run risk can be hard to isolate from the decision-makers' concern for the early (or late) resolution of uncertainty when externalities prevail".

Concerning the influence of CEO's attitude on his investment horizon behavior, analysis advanced in table 1 shows the presence of strong, negative and insignificant $(\beta=-0.2166)$ effect of CEO's locus of control; and, the presence of moderate, positive and significant $(\beta=0.0554)$ effect of CEO's myopia. While the influence of CEO's commitment bias on the investment horizon behavior, analysis advanced in table 1 shows the presence of a strong, negative and significant $(\beta=-0.0012)$ effect on investment horizon choice.

The irregularity of the link between the expressed attitudes and real behaviors is largely discussed in the set of the theory of persuasion (Girandola et al., 2008, Tenga et al., 2015) and the theory of commitment (Joule et al., 2007). These discussions were revealed by three principal aspects: the character of the instability of attitudes, the non-synchronization between the means of measure that evaluate person effective behaviors, and the weaker degree of correlation between attitudes and behaviors.

Furthermore, there is an indirect influence of commitment bias on investment horizon decision via its effect on CEO's myopic attitude (model 2). Commitment bias has a strong, positive and insignificant $(\beta=0.3023)$ effect on CEO's myopia. Also, there is an indirect influence of the CEO's locus of control on investment horizon decision via its effect on CEO's myopic attitude. CEO's locus of control has a moderate, negative and significant $(\beta=-0.0535)$ effect on CEO's myopia.

As the concept of "locus of control" expresses the notion of control that individual considers have over the events and tasks; managers with higher locus of control tend to be individuals who have great confidence in their capacity to perform right actions and to realize these tasks through determined work. Miller et al. (1982) show a direct link between the perceived locus of control and the nature of the strategy. This positive attitude increases the individual's confidence in self-ability and the perception of the facility of tasks which has a direct effect on behavioral attitude and intention (Hambrick, 2007).

Moreover, as displayed on table 2, there is an indirect influence of governance mechanisms on the investment horizon decision via its impact on CEO's myopic attitude. The results demonstrate that block holders and incentive remuneration systems encourage the myopic attitude of the manager, while independent directors encourage long-term attitudes. Consistently, Yafeh and Yosha (2003) confirm that ownership concentration is negatively associated with long-term behavior. In addition, the result generated by Czarnitzki and Kraft (2003) shows that ownership is more dispersed on companies that are engaged in long-term strategies.

Correspondingly, Jackson and Petraki (2011) explain this evidence by the fact that shareholders may decide and encourage myopic attitude and behaviors in order to eliminate insecurity about the long-run.

\subsection{Additional Analysis}

To validate the first model, we conduct two additional analyses. First, we analyze the investment horizon's choice variable as a target in the Bayesian network. Secondly, we analyze the Maximization of the Target Average.

\subsubsection{Analysis of the Target Variable (Horizon)}

We use the function that produces the analysis report of the target variable, according to this report, the correlation between the horizon and other variables are approximated by binary mutual information and the binary relative importance.

Table 3

Target variable analysis

\begin{tabular}{|c|c|c|c|c|}
\hline \multicolumn{5}{|c|}{ Horizon = long-term $(56.9903 \%)$} \\
\hline Nodes & Binary mutual information $^{(a)}$ & Binary relative importance ${ }^{(b)}$ & Modal va & \\
\hline $\mathbf{L C}$ & 0.0360 & 1.0000 & high & $71.9569 \%$ \\
\hline IRS & 0.0065 & 0.1796 & based-on performance & $71.4653 \%$ \\
\hline MYOP & 0.0022 & 0.0615 & high & $58.3204 \%$ \\
\hline OwC & 0.0009 & 0.0242 & yes & $73.2333 \%$ \\
\hline
\end{tabular}




\begin{tabular}{|c|c|c|c|c|}
\hline BIND & 0.0008 & 0.0217 & yes & $70.0755 \%$ \\
\hline CB & 0.0000 & 0.0000 & high & $74.9566 \%$ \\
\hline \multicolumn{5}{|c|}{ Horizon $=$ short-term $(43.0097 \%)$} \\
\hline Nodes & Binary mutual information $^{(a)}$ & Binary relative importance ${ }^{(b)}$ & \multicolumn{2}{|c|}{ Modal value(c) } \\
\hline $\mathbf{L C}$ & 0.0360 & 1.0000 & high & $89.6007 \%$ \\
\hline IRS & 0.0065 & 0.1796 & based-on performance & $79.6837 \%$ \\
\hline MYOP & 0.0022 & 0.0615 & high & $52.7669 \%$ \\
\hline OwC & 0.0009 & 0.0242 & yes & $76.2842 \%$ \\
\hline BIND & 0.0008 & 0.0217 & yes & $73.0705 \%$ \\
\hline CB & 0.0000 & 0.0000 & high & $75.0575 \%$ \\
\hline
\end{tabular}

The target variable analysis (horizon choice) shows that $56.9903 \%$ of Saudi companies decide long-term investment. Moreover, results show, for each value of the target, the list of nodes that have a probabilistic dependence with the target, sorted by descending order according to their relative contribution to the knowledge of the target value.

In the case of long-term investment, the most important nodes in term of informational relative contribution is, consecutively, the CEO's locus of control (Binary relative importance $=1.000$ ), the remuneration system (Binary relative importance $=0.1796$ ), the CEO's myopia (Binary relative importance $=0.0615$ ), the ownership concentration (Binary relative importance $=0.0242$ ), the presence of outside directors (Binary relative importance $=0.0217$ ), and, the CEO's commitment bias (Binary relative importance $=0.0000$ ).

While, in the case of short-term investment, the most important nodes in term of informational relative contribution is, consecutively, the CEO's locus of control (Binary relative importance=1.000), the based on performance remuneration system (Binary relative importance $=0.1796$ ), the CEO's myopia (Binary relative importance $=0.0615$ ), the ownership concentration (Binary relative importance $=0.0242$ ), the presence of outside directors (Binary relative importance $=0.0217$ ), and, the CEO's commitment bias (Binary relative importance $=0.0000$ ).

In the case of long-term investment, the most important modal value is given respectively by the node of the CEO's commitment bias ( modal value $=74.9566 \%$ ); the ownership concentration (modal value $=73.2333 \%$ ); the based on performance remuneration system (modal value $=71.4653 \%$ ), the presence of outside directors (modal value $=70.0755 \%$ ); and, the CEO's myopia (modal value $=58.3204 \%$ ).

While, in the case of short-term investment, the most important modal value is given by the CEO's locus of control (modal value $=89.6007 \%$ ); the based on performance remuneration system (modal value $=79.6837 \%$ ); the ownership concentration ( modal value $=76.2842 \%$ ); the CEO's commitment bias (modal value $=75.0575 \% \%$ ); the presence of outside directors (modal value $=73.0705 \%)$; and, the CEO's short-term attitude $($ myopia $)($ modal value $=52.7669 \%)$.

Therefore, it is demonstrated that commitment bias is the most important variable in terms of modal value to explain the manager behavior in investment horizon choice. This importance may be explained by the theory of planned behavior (Ajzen, 1985, 1991, 2012) which show that either the manager attitude (myopia, locus of control) or the organizational norms (ownership concentration, board independence, and remuneration system) can influence the CEOs behavior intention, but, the power of the commitment bias refers to the direct relationship between the preparatory act and the person's behavior.

Similarly, Ajzen $(1985,1991)$ argues that certain behaviors require resources, skills, and opportunities to which the individual has no control. To take account of these barriers, he adds a third variable: "perceived behavioral control", which corresponds to the individual's perception of the facility or difficulty to accomplish a specific behavior.

So, three factors are taken into consideration to explain the adoption by an individual of a particular behavior: its attitude toward the behavior (cognition and consequences evaluation), subjective norms relating to its behavior in question (organizational pressure and motivation to compliance) and the perception of control over the behavior (resources, capabilities and opportunities available to behavior accomplishment "locus of control").

\subsubsection{Maximization of the Target Average (Horizon)}

The target dynamic profile capability is a test enhanced by BayesiaLab program to provide the percentage of the explanatory variable in maximizing the target variable value. Table 4 presents the dynamic profile of the Investment horizon choice (HORIZON). The target dynamic profile analysis shows two important results. First, with the 56,9903\% rise in long-term investment it is associated with an augmentation in the effect of based-on performance remuneration system with $100 \%$; the decrease in the effect of myopic attitude with $98,8215 \%$; the decrease in the influence of the board independence with $82,8977 \%$; finally, the decrease in the effect of CEO's locus of control with $78.1334 \%$. Secondly, with the $43.0097 \%$ decrease in long-term investment it is associated with an augmentation in the effect of ownership concentration with $60,0000 \%$, the decrease in the effect of CEO's myopia with $57.8792 \%$; the increase in the effect of board dependency with $55.1284 \%$; the increase in the effect of based-on performance remuneration system with $51.7182 \%$, and the increase in the effect of CEO's locus of control with $48.4465 \%$. Since the Rotter's Internal-External Locus of control scale measures the degree to which 
individuals think they have control over their behaviors (internal LC) or the degree to which their actions are controlled by chance or environment (external LC), it is advanced as an indicator of efficiency in a corporation strategy especially the internal LC variable. Managers with an internal locus of control (internals) tend to improve better performance progress because they have the higher professional desire of accomplishment and earnings and attempt higher performance ratings than managers with an external locus of control (externals). Therefore, internals employ more efforts to control their environment, display superior competences, search new information more dynamically, and utilize information efficiently than externals (Tang et al., 1997). The results may be justified by the affirmation of Tang et al. (1997) which suggested that task specificity may characterize the interpretation of the task, but its evaluation depends on both that specificity and the personal and cognitive characteristics of the individual. Based on these affirmations, the authors express that Internal-External locus of control will be explored as a representative variable for the relationship between self-reported performance feedback and organizational commitment. Thus, persons with an internal locus of control may have higher control over their actions, may be less influenced by external information, and, maybe less probable to have important changes in their commitment level after performance feedback. Contradictory, managers with an external locus of control may be intensely impacted by the performance feedback. Consequently, they may display high (low) commitment when their performance level is high (low).

Table 4

Target dynamic profile analysis

\begin{tabular}{|c|c|c|c|}
\hline \multicolumn{4}{|c|}{ Horizon $=$ long-term } \\
\hline Nodes & Optimal modality & Probability & Joint Probability \\
\hline A priori & & $56.9903 \%$ & $100.0000 \%$ \\
\hline LC & low & $78.1334 \%$ & $20.4545 \%$ \\
\hline BIND & no & $82.8977 \%$ & $5.8574 \%$ \\
\hline MYOP & low & $98.8215 \%$ & $1.9769 \%$ \\
\hline IRS & based-on performance & $100.0000 \%$ & $1.1083 \%$ \\
\hline \multicolumn{4}{|c|}{ Horizon $=$ short-term } \\
\hline Nodes & Optimal modality & Probability & Joint Probability \\
\hline A priori & & $43.0097 \%$ & $100.0000 \%$ \\
\hline LC & high & $48.4465 \%$ & $79.5455 \%$ \\
\hline IRS & based-on performance & $51.7182 \%$ & $59.6591 \%$ \\
\hline BIND & yes & $55.1284 \%$ & $42.5749 \%$ \\
\hline MYOP & low & $57.8792 \%$ & $18.6165 \%$ \\
\hline OwC & no & $60.0000 \%$ & $4.7977 \%$ \\
\hline
\end{tabular}

\section{Conclusion and recommendations}

The evolution of investment appraisal, especially investment horizon, has been of great interest to financial researchers. Much early work focuses on the organizational determinants of investment horizon choice to mitigate short-term problems, leading directly to debates about their effect on firm performance and value. More recently, studies look into the behavioral determinants, the other facet of decision-making. Studying how organizational and behavioral determinants influence investment choices is important to our understanding of these key decisions. In this study, we are particularly interested in how ownership concentration, board independence, and executive compensation, as organizational determinants, affect managers' choices and their myopic attitude. Also, we are interested in showing the impact of executives' commitment bias, the locus of control and myopia on their investment horizon choices. Furthermore, we studied the influence of managers' commitment bias and locus of control on their myopic attitude. The built theoretical model aimed to resolve the question of the managerial discretion' determinants through enrichment of the Charreaux' model (2008) by advancing the notion of cognitive commitment and locus of control as parts of the managers' mental pattern. We find evidence that the relationship between governance mechanisms, the manager's attitude and behavior demonstrate that a short-term vision is not intrinsically undesirable by block holders. Equally, looking to specific behavioral biases, wrong decisions may also be engaged in the long term perspective. Therefore, the argument that governance mechanisms may discipline mainly and essentially managers should not take margins on the topic. However, executives decide the investment term considering a diversity of variables, including their attitude toward a myopic decision, their level of commitment, and their locus of control perception. Additionally, results indicate that in these circumstances, managers are unlikely to consider the great involvement of shareholders in the short term because of the absence of pay for performance incentives. Similarly, managers' myopic attitudes are not likely to modify their investment horizon behaviors. In essence, it is improbable that managers' comportment will change without the vital psychological commitment. Predominantly, we can attest that the main lesson of this research for Saudi companies is to believe that the time is suitable to revisit the concept of appropriate corporate governance system with a long-term vision by including the binding communication to powerfully manage the managers' decisional latitude.

\section{Acknowledgement}

This research was funded by the Deanship of Scientific Research at Princess Nourah bint Abdulrahman University through the Fast-track Research Funding Program. 


\section{References}

Agrawal, A., \& Mandelker G. (1990). Large Shareholders and the Monitoring of Managers: The Case of Antitakeover Charter Amendments. Journal of Financial and Quantitative Analysis, 25(2), 143-167.

Ajzen, I. \& Sheikh, S., (2013). Action versus inaction: Anticipated affect in the theory of planned behavior. Journal of Applied Social Psychology, 43, 155-162.

Ajzen, I. (1985). From intentions to actions: A theory of planned behavior. In J. Kuhi \& J. Beckmann (Eds.), Action-control: From cognition to behavior (pp. 11-39). Heidelberg: Springer

Ajzen, I. (1991). The theory of planned behavior. Organizational Behavior and Human Decision Processes, 50(2), $179-211$. http://doi:10.1016/0749-5978(91)90020-T.

Ajzen, I. (2012). Attitudes and persuasion. In K. Deaux \& M. Snyder (Eds.), The Oxford Handbook of Personality and Social Psychology (pp. 367-393). New York: Oxford University Press

Argyris, C. (1999). On Organizational Learning. (2 $2^{\text {nd }}$ ed.). Malden, MA: Blackwell Publishing.

Ashbaugh-Skaife, H., D.W. Collins, W.R. Kinney \& R. LaFond. (2009). The effect of SOX internal control deficiencies on firm risk and cost of equity. Journal of Accounting Research, 47, 1-43

Bamberg, S. \& Möser G., (2007). Twenty years after Hines, Hungerford, and Tomera: A new meta-analysis of psychosocial determinants of pro-environmental behavior. Journal of Environmental Psychology 27, 14-25

Baz, J., E. Briys, B.J. Bronnenberg, M. Cohen, R. Kast, P. Viala, L. Wathieu, M. Weber, \& K. Wertenbroch. (1999). Risk Perception in the Short Run and in the Long Run. Marketing Letters, 10(3), 267-283.

Bonetto, E., Adam-Troian, J., Varet, F., Monaco, G. L., \& Girandola, F. (2018). Priming Resistance to Persuasion decreases adherence to Conspiracy Theories. Social Influence, 13(3), 125-136

Charreaux, G. (2008). À la recherche du lien perdu entre caractéristiques des dirigeants et performance de la firme : gouvernance et latitude managériale. Cahier du FARGO n 1080502.

Czarnitzki, D. \& K. Kraft (2003). Management control and innovative activity. Review of Industrial Organization, 24(1), 1-24

Dallas, L. L. (2012). Short-Termism, the Financial Crisis, and Corporate Governance. Journal of Corporation Law, 37(2), 264-354

Daniel, K., Hirshleifer, D., \& Teoh, S. (2002). Investor psychology in capital markets: Evidence and Policy Implications. Journal of Monetary Economics, 49, 139-209.

De Bondt, W. (1998). A Portrait of the Individual Investor. European Economic Review, 42, 831-844.

Durand, R. (2003). Predicting a firm's forecasting ability: The role of organizational illusion of control and organizational attention. Strategic Management Journal, 24, 821- 838.

Duruigbo, E. (2011). Tackling Shareholder Short-Termism and Managerial Myopia. Kentucky Law Journal, 100, 531-584

Fama, E.F. (1980). Agency problems and the theory of the firm. Journal of Political Economy, 88, 1980.

Fama, E.F., \&, Jensen, M.C., (1983). Separation of ownership and control. Journal of Law and Economics 26, 301-325

Feather, N. T., \&, Newton, J. W. (1982). Values, expectations, and the prediction of social action: An expectancy-valence analysis. Motivation \& Emotion, 6, 217-244.

Finkelstein, S. \& Hambrick, D. (1996). Strategic Leadership: Top executives and their effects on organizations. Minneapolis, St. Paul: West Publishing Company.

Fishbein, M. (1963). An investigation of the relationship between beliefs about an object and the attitude toward that object. Human Relations, 16, 233-239.

Fishbein, M., \& Ajzen, L. (1975). Belief, attitude, intention, and behavior: An introduction to theory and research. Reading, MA: Addison-Wesley.

Girandola, F., Michelik, F., \&, Joule, R.-V. (2008). Promouvoir la pratique physique chez les étudiants: communication et communication engageante. 4ème Journées de la prévention INPES, 10-11 avril, Paris (France).

Gonzalez, A., \& André P. (2014). Board Effectiveness and Short Termism. Journal of Business Finance \& Accounting, 41(1-2), $185-209$

Gutiérrez, G. \& Philippon, T. (2016, December). Investment-less growth: An empirical investigation. Mimeo NYU, 2016.

Gutiérrez, G. \& Philippon, T. (2017) Competition and investment. Mimeo NYU, 2017.

Hambrick, D.C., \&, Abrahamson, E. (1995). Assessing the Amount of Managerial Discretion In Different Industries. Academy of Management Journal, 38, 1427-1441

Hambrick, D. C., Finkelstein, S., \& Mooney, A. C. (2005). Executive job demands: New insights for explaining strategic decisions and leader behaviors. Academy of Management Review, 30, 472- 491

Hambrick, D.C (2007), The field of management's devotion to theory: too much of a good thing? Academy of Management Journal, $50(6), 1346-1352$

Hamza, F., Azouzi, M.A., \& Jarboui, A., (2014). CEO's commitment bias, ownership concentration, and innovation decision: Behavioral management of CEO's discretion. Cogent Economics \& Finance, 2(1).

Hawley, J. P. \& Williams, A. T. (2000b). The Rise of Fiduciary Capitalism. University of Pennsylvania Press: Philadelphia.

Hill, J.G. (2007). Pension Funds Must Heed Climate Change. http://www.reuters.com/article/Accessed 14 March 2007.

Hill, J.G. (2010). Then and Now: Professor Berle and the Unpredictable Shareholder. Seattle University Law Review, 33(4), 10051023.

Hiller, N., \& Hambrick, D. (2005). Conceptualizing executive hubris: The role of core self-evaluations in strategic decision-making. Strategic Management Journal, 26, 297-319

Hilton, J. D. (2001). The psychology of financial decision-making: Application to trading, dealing, and investment analysis. The Journal of Psychology and Financial Markets, 2, 37-53.

Holderness, C.G. (2002). A Survey of Blockholders and Corporate Control. Economic Policy Review. 
Jackson, G. \& Petraki A. (2011). Understanding Short-termism: the Role of Corporate Governance. Report to the Glasshouse Forum 2011

Jackson, T., Weiss, K.E., \& Lundquist J.J. (2000). Does procrastination mediate the relationship between optimism and subsequent stress? Journal of Social Behavior and Personality, 15, 203-212

Janssen, T., \& Carton, J. S. (1999). The effects of locus of control and task difficulty on procrastination. Journal of Genetic Psychology, 160(4), 436-442.

Jeffrey, P. (2005). Attitudes and Perceptions. Available at: http://healthadmin.jbpub.com/borkowski/chapter3.pdf

Jensen, M.C, \& Murphy K.J. (1990). Performance Pay and Top-Management Incentives. Journal of Political Economy, 98 (2), $225-264$

Jesse M. F. (2011). Share Repurchases, Equity Issuances, and the Optimal Design of Executive Pay. Texas Law Review, 89( 5), 1113,2011

Joule, R.V., Girandola, F., \& Bernard, F. (2007). How can people be induced to willingly change their behavior? The path from persuasive communication to committing communication. Social and Personality Psychology Compass, 1, 493-505

Kahneman, D. \& Riepe, M. W. (1998). Aspects of investor psychology. The Journal of Portfolio Management, 52-65.

Ke Zhang (2018). Theory of Planned Behavior: Origins, Development and Future Direction. International Journal of Humanities and Social Science Invention (IJHSSI), 7(5), 76-83

Laverty, K. (1996). Economic "Short-Termism": The Debate, the Unresolved Issues, and the Implications for Management Practice and Research. The Academy of Management Review, 21(3), 825-860

Leslie, M.B, (2010). Helping Nonprofits Police Themselves: What Trust Law Can Teach Us About Conflicts of Interest. ChicagoKent law review, 85, 551, 561

Meyer, J. P., Stanley, D. J., Herscovitch, L. \& Topolnytsky, L. (2002). Affective, Continuance and Normative Commitment to the Organization: A Meta-analysis of Antecedents, Correlates, and Consequences. Journal of Vocational Behavior, 61, $20-52$.

Miller, D., Kets de Vries, M.F.R. \& Toulouse, J.-M. (1982). Top executive locus of control and its relationship to strategy-making, structure, and environment. Academy of Management Journal, 25(2), 237-253.

Mitchell, J.R., Hart, T.A., Valcea, S., \& Townsend, D.M. (2009). Becoming the boss: Discretion and post-succession success in family firms. Entrepreneurship Theory and Practice, 33(6), 1201-1218.

Murphy, K.J. (1999). Executive compensation. In Handbook of Labor Economics,3B, (Eds). OAshenfelter, D Card, (pp. 2485-563). Amsterdam: Elsevier/North-Holland

Papenhausen, C. (2006). Half full or half empty: The effects of top manager's dispositional optimism on strategic decision-making and firm performance. Journal of Behavioral and Applied Management, 7, 103-115

Plante, I., O'Keefe, P.A, \& Théorêt, M. (2012). The relation between achievement goal and expectancy-value theories in predicting achievement-related outcomes: A test of four theoretical conceptions. Springer Science and Business Media.

Rappaport, A. (2005). The Economics of Short-Term Performance Obsession. Financial Analysts Journal, 61(3), 65-79

Rotter, J.B. (1966), Generalized Expectancies for Internal versus External Control of Reinforcement. Psychological Monographs: General and Applied, 80(609), 1-28.

Rubin, A., \& Segal, D. (2011). Board Reputation and Financial Reporting Quality. Available at http://www.insead.edu/facultyresearch/areas/accounting/events/documents/BoardReputationandFinancialReportingQualityPaper.pdf

Sappideen, R. (2011). Focusing on corporate short-termism. Singapore Journal of Legal Studies, (Dec 2011), 412-431.

Shabou, R., (2000). Nature des détenteurs de blocs de contrôle, mécanismes de contrôle et performance financière des entreprises tunisiennes. Working paper. University of Sfax.

Shleifer, A., \& Vishny, R.W. (1986). Large Shareholders and Corporate Control. The Journal of Political Economy, 94(3), 461-488

Tang, T. L-P, Baldwin, L.J \& Alan G. Frost, A.G. (1997). Locus of control as a moderator of the selfreported performance feedbackpersonal sacrifice relationship. Personality and Individual Differences Journal. 22(2), 201-211.

Tenga, S., Wei Khonga, K., \& Wei Gohb W. (2015). Persuasive Communication: A Study of Major Attitude-Behavior Theories in a Social Media Context. Journal of Internet Commerce, 14(1), 42-64

Wally, S. \& Baum, J.R. (1994). Personal and Structural Determinants of the Pace of Strategic Decision-Making. Academy of Management Journal, 37, 932-956

Warneryd, K. E. (2001). Stock-market psychology: How people value and trade Stocks. Edward Elgar: Northampton.

Warren, Geoff (2014a). Long-Term Investing: What Determines Investment Horizon?. CIFR Research Working Paper, May ('Paper 1')

Williams, C.A., \& Conley, J. (2005). An Emerging Third Way?: The Erosion of the AngloAmerican Shareholder Value Construct. Cornell International Law Journal, 38(2), 493-551.

Wirtz, P. (2011): The cognitive dimension of corporate governance in fast growing entrepreneurial firms. European Management Journal, 29, 431- 447

Yafeh, Y. \& Yosha, O. (2003). Large Shareholders and Banks: Who Monitors and How?. The Economic Journal, 113(484), 128146.

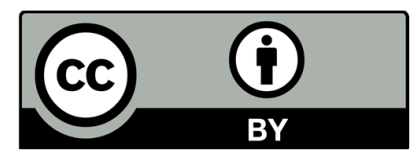

(C) 2022 by the authors; licensee Growing Science, Canada. This is an open access article distributed under the terms and conditions of the Creative Commons Attribution (CC-BY) license (http://creativecommons.org/licenses/by/4.0/). 